\title{
CHD pile performance: part I - physical modelling
}

1 John Ross Jeffrey MEng, PhD Geotechnical Engineer, Technip UK Limited, Westhill, UK

2 Michael John Brown BEng, PhD

Senior Lecturer, Division of Civil Engineering, University of Dundee, Dundee, UK (corresponding author: m.j.z.brown@dundee.ac.uk)

3 Jonathan Adam Knappett MA, MEng, PhD

Reader, School of Science \& Engineering, University of Dundee,

Dundee, UK
4 Jonathan David Ball BSC, CGeol, FGS

Chief Geotechnical Engineer, Roger Bullivant Ltd, Burton Upon Trent, UK

5 Karlis Caucis MEng

Graduate Engineer, Arup, South Queensferry, UK
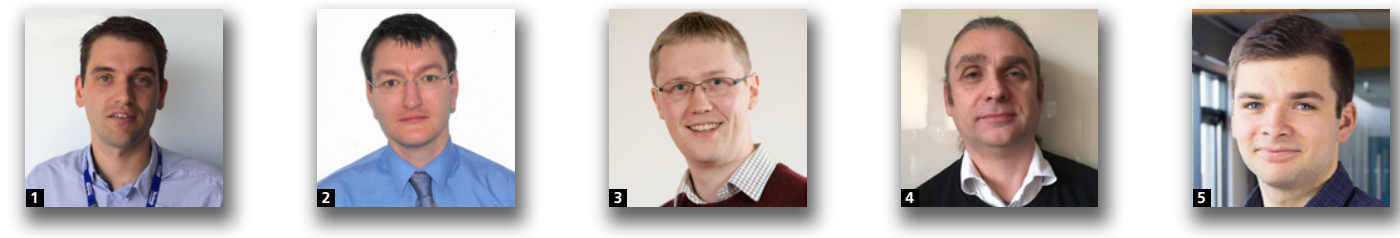

The continuous helical displacement (CHD) pile is an auger displacement pile developed in the UK. It has performance characteristics of both displacement and non-displacement piles due to the way in which it is installed. Based on field experience, it has been shown that the load-settlement performance of CHD piles installed in sand exceeds the current design predictions based upon conservative effective pile diameter and design parameters associated with auger bored or continuous flight auger in situ piles. In an effort to gain a greater understanding of the performance of CHD piles in sand compared with more conventional piling techniques, a programme of physical model pile testing (reported in this paper) and associated finite-element modelling (reported in a companion paper) was undertaken. The model testing programme established that greater shaft resistance may be developed for the piles than had originally been considered. Based upon the results of the model testing, recommendations for more appropriate approaches to the selection of end bearing and shaft resistance factors are made to predict ultimate load capacity in sand.

\section{Notation}

$A_{\mathrm{b}} \quad$ area of pile base

$A_{\mathrm{s}} \quad$ area of pile shaft

D pile diameter

$D_{\mathrm{CPT}} \quad$ diameter of cone penetration test (CPT) probe

$D_{\text {c }} \quad$ continuous helical displacement (CHD) pile core diameter

$D_{\text {e }} \quad$ CHD pile effective design diameter

$D_{\mathrm{f}} \quad$ CHD pile outer flight or flange diameter

$D_{\mathrm{r}} \quad$ relative density of soil

$D_{10} \quad$ particle size for $10 \%$ passing

$D_{50} \quad$ mean particle size

$h \quad$ height above pile base

$K \quad$ coefficient of lateral earth pressure

$L \quad$ pile length

$N_{\mathrm{q}} \quad$ bearing capacity factor

$Q_{\mathrm{b}} \quad$ pile base capacity

$Q_{\text {s }} \quad$ pile shaft capacity

$Q_{\mathrm{T}} \quad$ total pile capacity

$q_{\mathrm{c}} \quad$ CPT cone resistance

$q_{\mathrm{c} 3 \cdot 3 D}$

$\begin{array}{ll}T & \text { measured torque } \\ w & \text { pile settlement } \\ z & \text { penetration depth } \\ \delta^{\prime} & \text { interface friction angle } \\ \delta_{\text {crit }} & \text { interface friction angle (critical state) } \\ \delta_{\mathrm{p}} & \text { interface friction angle (peak) } \\ \rho_{\max } & \text { maximum density of dry soil } \\ \rho_{\min } & \text { minimum density of dry soil } \\ \sigma_{\mathrm{v}}^{\prime} & \text { vertical effective stress } \\ \phi^{\prime} & \text { angle of internal friction } \\ \phi_{\mathrm{p}}^{\prime} & \text { peak angle of friction }\end{array}$

\section{Introduction}

The continuous helical displacement (CHD) piling system is a form of cast in situ auger displacement pile that may be classified as a type of screw pile. As with driven/displacement piles, the soil is displaced around the CHD tool during installation, which is assumed to result in improved pile performance. Compared with the installation of displacement piles, however, there is limited vibration, noise and spoil associated with 
Geotechnical Engineering

Volume 169 Issue GE5
CHD pile performance: part I - physical

modelling

Jeffrey, Brown, Knappett, Ball and Caucis
CHD piling, making the technique suited for use in congested urban environments (van Impe, 2004). The lack of spoil, due to the lateral soil displacement (Grabe et al., 2013), makes it additionally suitable where contaminated soil is encountered (Wade et al., 2012).

The CHD pile is formed using a tool referred to as a 'bullet' (Figure 1(a)) having a hollow central core with a helical flight around the outside. The bullet is attached to a hollow delivery shaft and is rotated into the ground using a high-torque drilling rig (Figure 1(b)). The penetration rate of the bullet varies depending on in situ ground conditions, but a typical advance rate is $58 \mathrm{~mm} / \mathrm{s}$. Once at an appropriate depth, concrete is pumped under pressure down through the hollow shaft where a disposable tip at the end of the bullet (to prevent soil ingress) is blown out. Once concrete is flowing, the bullet is rotated in the opposite direction to the installation with an upward motion. The pressurised concrete fills the void created by the retreating bullet, forming the CHD pile.

Completed CHD piles have a non-uniform cross-section along the pile length, as shown in Figure 2. In terms of design, the varying cross-section makes the definition of an appropriate diameter open to interpretation. For instance, the effective diameter $\left(D_{\mathrm{e}}\right)$ of the Atlas auger displacement pile has been defined in various ways, including $D_{\mathrm{e}}=1 \cdot 1 D_{\mathrm{c}}\left(D_{\mathrm{c}}\right.$ being the core diameter $), D_{\mathrm{e}}=D_{\mathrm{f}}$ ( $D_{\mathrm{f}}$ is the outer flight/flange diameter (van Impe, 1988)) or $D_{\mathrm{e}}=0.9 D_{\mathrm{f}}$ (Bustamante and Gianeselli, 1993). For a CHD pile, the effective diameter has typically been taken as $0 \cdot 75 D_{\mathrm{f}}$; that is, the average of $D_{\mathrm{c}}$ and $D_{\mathrm{f}}$ based on an investigation of full-scale field testing results (the ranges of pile diameters considered were $D_{\mathrm{f}}=450-600 \mathrm{~mm}$ and $D_{\mathrm{c}}=225$ $340 \mathrm{~mm}$ ) carried out by the Geotechnical Consulting Group (GCG, 1998). This assumption appears to be conservative when compared with similar auger displacement piles.

CHD piles, along with other similar types of displacement piles, have been found to perform well in terms of loadsettlement behaviour in a variety of soil conditions (Bell, 2010). There have been many instances where the ultimate load capacity of the CHD pile has significantly exceeded current design predictions (Jeffrey et al., 2010) that typically have their origins in continuous flight auger (CFA) pile design, which has been shown to be conservative (Gavin et al., 2009). This is attributed to the conservative assumptions of effective diameter noted previously and conservative parameter selection for the calculation of shaft capacity. There is also evidence to suggest that the soil surrounding displacement piles is altered by the

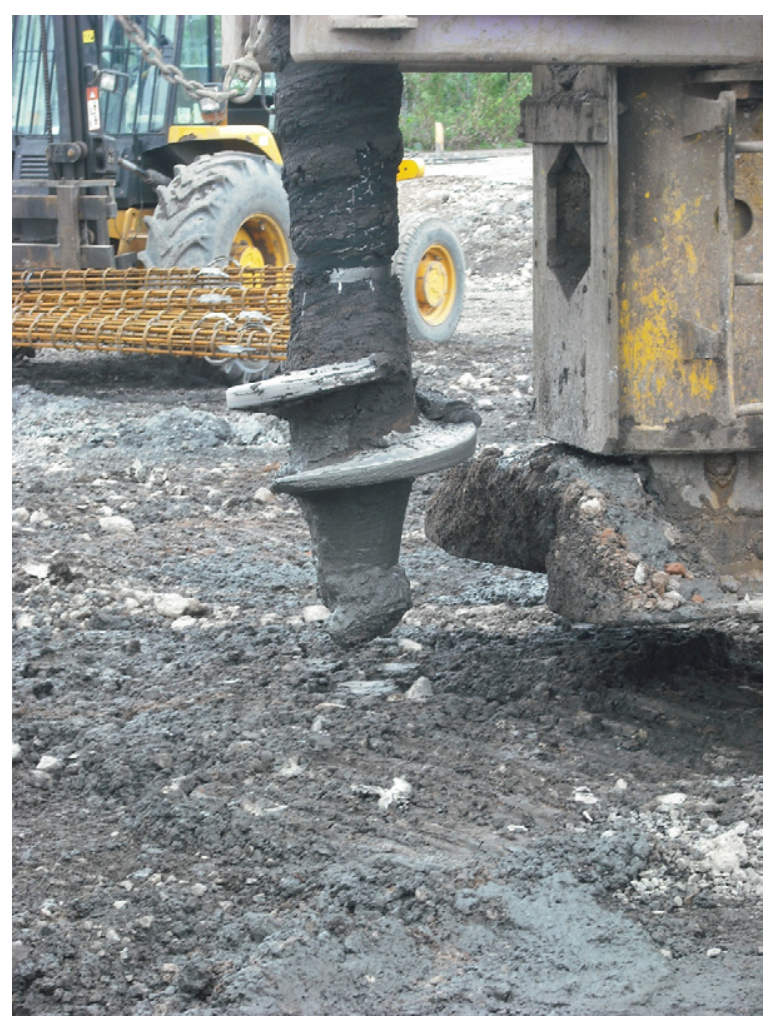

(a)

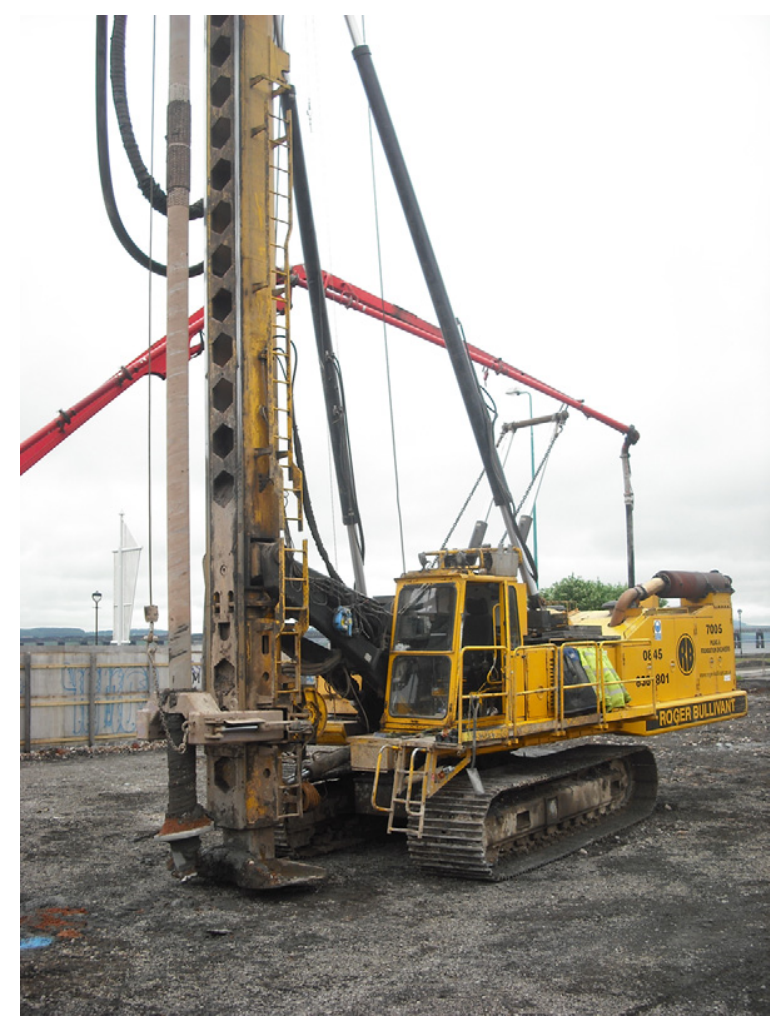

(b)

Figure 1. (a) CHD pile formation tool or 'bullet'. (b) CHD pile installation drilling rig 


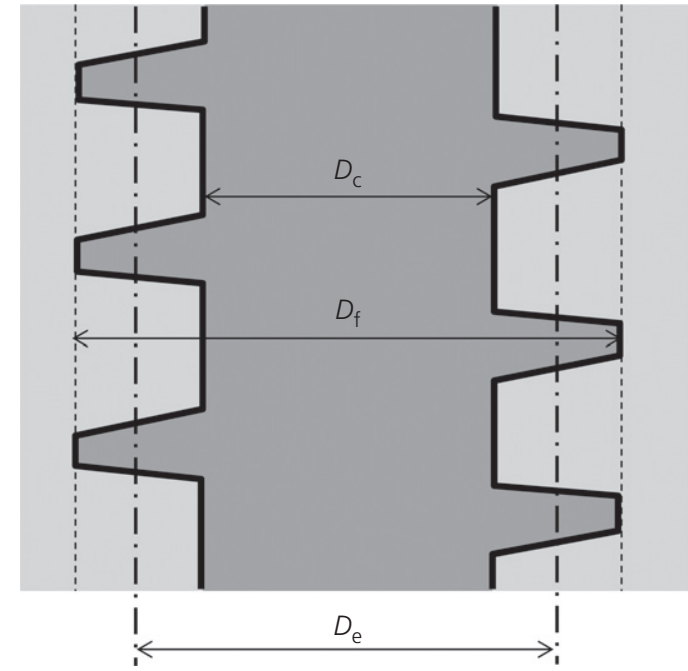

Figure 2. Schematic illustration of idealised CHD pile cross-section and definition of geometrical parameters

installation process. To reflect this behaviour, design may normally be based on in situ testing (e.g. cone penetration test (CPT)), which has been assumed to mimic the installation process to some extent (Bustamante and Gianeselli, 1993). Where CPT data are not available, classic design assumptions are made based upon assumed end bearing and effective stress parameters (for CFA piles as discussed above), which may not capture the greater load-carrying capacities, particularly in coarse-grained soils (Bell, 2010; Busch et al., 2010).

In order to refine the design process and gain a greater understanding of CHD pile behaviour, a 1:10 scale model pile construction system was developed that allowed the in situ formation of model CHD piles with realistic geometry in sand at varying relative densities. To complement the model testing, finite-element modelling (FEM) of the CHD piles, using a stress-dependent constitutive model, was also conducted and validated against the experimental data (at small scale) and against field pile load test data (full scale). This paper focuses on the $1 \mathrm{~g}$ laboratory physical modelling and proposes refinements to current (capacity-based) analytical design techniques. The companion paper (Knappett et al., 2016) describes the non-linear FEM, which was developed as a simple tool for predicting load-settlement behaviour (at the serviceability limit state) and which, like the analytical approaches, only requires routinely available site investigation data and access to commercially available FEM software.

\section{Model testing apparatus and methodology}

To allow a comparison of performance, in addition to the CHD piles, jacked and wished-in-place (WIP) piles were also modelled to represent traditional displacement and nondisplacement pile types, respectively.

\subsection{Test configuration and sand bed preparation}

Installation of the model piles was carried out in dry sand test beds prepared using air pluviation (Ueno, 2000) in which the sand was passed through varying mesh sizes in order to vary the relative density $\left(D_{\mathrm{r}}\right)$ of the test beds (typical ranges investigated were loose $\left(D_{\mathrm{r}}=18-22 \%\right)$, medium dense $\left(D_{\mathrm{r}}=48-63 \%\right)$ and dense $\left(D_{\mathrm{r}}=78-85 \%\right)$, with exact values stated where appropriate). Relative density was measured directly for each test bed by including a density pot at the base of the test box (and away from the pile centreline) prior to pluviation. This was carefully exhumed at the end of testing and the density verified. In addition, the pluviator slot widths were carefully calibrated against the relative density of dummy samples to minimise variation between test beds. The sand used in the test beds was uniform Congleton fine silica sand (henceforth termed HST95 (Lauder et al., 2013)). The maximum density of dry sand was $\rho_{\max }=1792 \mathrm{~kg} / \mathrm{m}^{3}$, the minimum dry density was $\rho_{\text {min }}=1487 \mathrm{~kg} / \mathrm{m}^{3}$, particle sizes were $D_{50}=0.14 \mathrm{~mm}$ and $D_{10}=0.10 \mathrm{~mm}$, and the sand had a critical state friction angle of $32^{\circ}$ as determined in the direct shear box. The grain size $\left(D_{50}\right)$ to pile or CPT diameter ratio used in this study was a minimum of 114 (for the $16 \mathrm{~mm}$ CPT probe described later), greatly exceeding the ratio of 20 at which grain size issues are thought to influence penetration resistance (Philips and Valsangkar, 1987) and the larger suggested range of $35 D_{50}$ to $65 D_{50}$ proposed by Garnier et al. (2007).

The soil beds were produced in a rigid aluminium box with internal dimensions of $420 \mathrm{~mm} \times 420 \mathrm{~mm}$ and $660 \mathrm{~mm}$ depth. Sand was pluviated to a depth of $600 \mathrm{~mm}$, resulting in a test sand bed of $7 D \times 7 D$ by $10 D$ depth, where the pile diameter $D=60 \mathrm{~mm}(600 \mathrm{~mm}$ at prototype scale) was the maximum flange diameter over the majority of the CHD pile length and the diameter of the largest jacked and WIP piles. Trials conducted by Philips and Valsangkar (1987) suggest that radial boundary effects for penetrating objects are not significant where the separation of the object from the side wall is $5 D$ or greater ( $5 D$ was the lowest separation investigated) even in dense soils (at low confining stresses). CPT testing in calibration chambers reported by Bolton et al. (1999) indicated that a minimum distance of 15 probe diameters was required between the probe and the rigid boundary to preclude boundary effects. To minimise the potential for radial boundary effects, the side wall of the box was lined with a $1 \mathrm{~mm}$ thick polytetrafluoroethylene (PTFE) sheet (PTFE has a friction coefficient of 0.04 compared with 0.61 for aluminium according to Young and Freedman (2000)). This was done to minimise errors in settlement measurements, as Randolph and Wroth (1978) showed that mobilised shear stress around a pile decayed on travelling only a short distance from a pile but that settlements may extend some distance from the pile shaft. Therefore, with the low confining stresses and friction-reducing PTFE used in this study, $3.5 \mathrm{D}$ separation was considered adequate for accurate measurements of pile resistance, although it is acknowledged that the proximity of the boundaries has the 


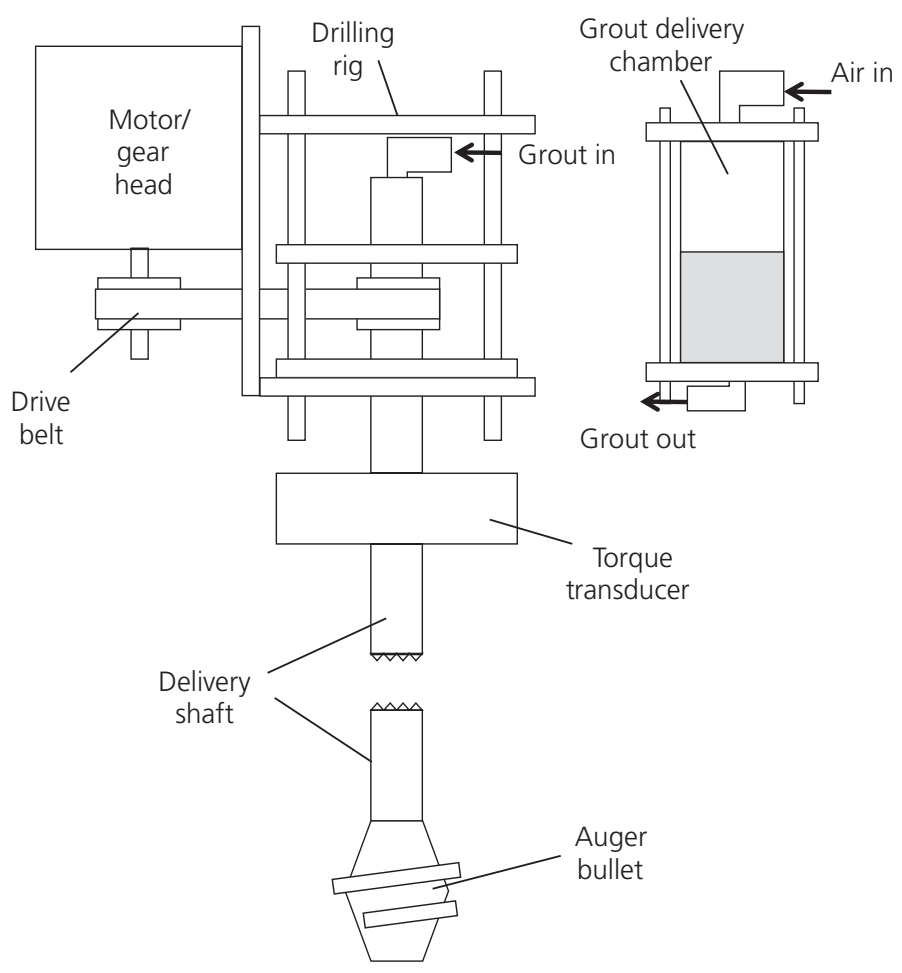

(a)

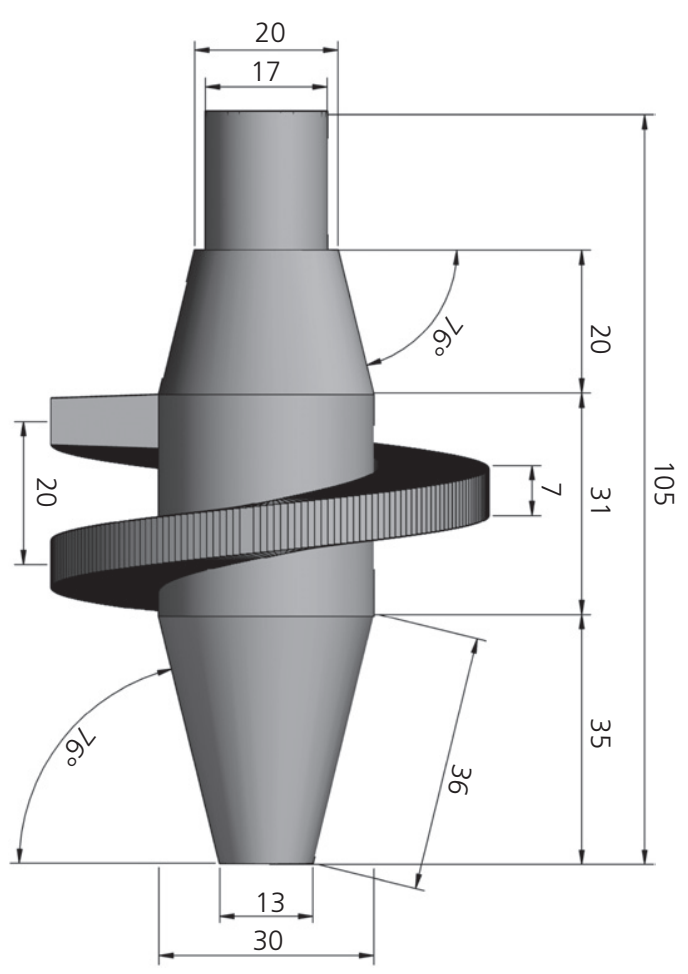

(b)

Figure 3. Schematic diagram of (a) model CHD pile drilling

rig and grouting system and (b) auger bullet dimensions

(all dimensions in $\mathrm{mm}$ )

potential to lead to enhanced lateral earth pressures being created during installation. Determining the minimum separation below the base of the pile and the base of the box was less straightforward for the final CHD pile as the base of the pile had a diameter of $13 \mathrm{~mm}$ at the tip, increasing to $30 \mathrm{~mm}$ (40-60 $\mathrm{mm}$ above) at the base of the first flange $(15 \cdot 2 \mathrm{D}$ or 8-8.7D). Philips and Valsangkar (1987) state that the influence of the bottom boundary may be felt at 10-12 diameters of a probing object. Thus, due to the variable tip geometry, the decision was made to investigate the presence of base separation on loading results using FEM of a CHD pile installed in medium dense sand $\left(D_{\mathrm{r}}=59 \%\right)$ with no effect being noted. This is reported in the companion paper (Knappett et al., 2016).

\subsection{Model CHD pile installation}

A 1:10 scale model CHD auger bullet was manufactured from stainless steel along with the necessary grout/concrete delivery shaft. The bullet and shaft formed part of a specially manufactured model CHD pile drilling rig, shown in Figure 3. A DC electric motor provided the required rotational movement of the CHD bullet. This was transferred to the delivery shaft by way of a belt drive system, while an Instron 1196 universal load frame controlled the vertical movement in displacement-controlled mode. The relationship between vertical movement and rotational speed has been found to influence significantly the quality of both CFA and CHD pile formation (Thorburn et al., 1993). For the vertical penetration rate of $500 \mathrm{~mm} / \mathrm{min}$ adopted in this study, the optimal rotational speed to match a 'screwing in' effect was found to be $22 \mathrm{rpm}$ for pile formation during both installation and withdrawal. The effect of different installation rates on pile performance was not investigated during this study and a neutral rate, predetermined by the auger bullet geometry, was adopted. A specially manufactured inline torque transducer with central grout delivery void (rated to $25 \mathrm{kN} . \mathrm{m}$ ) was used to record the torque applied to the auger bullet and shaft during the installation process.

The model piles were constructed from a rapid-hardening Portland cement grout with a water/cement ratio of 0.55 (by mass). Once the bullet had penetrated to the desired pile tip depth, grout was pumped through the delivery shaft from a pressure-rated storage chamber using air at 0.5 bar $(50 \mathrm{kPa})$. The grout consisted of pure cement paste instead of concrete to facilitate pumping as it was found that using any form of aggregate in the grout led to blockages. Although the stiffness of the cement paste was not directly measured, these pastes typically have a maximum Young's modulus of $29 \mathrm{MPa}$, which 
reduces with porosity (Mindess et al., 2003) or water/cement ratio (typical range 20-29 $\mathrm{MPa}$ ). This compares favourably with the range of stiffness for cast in situ pile concrete of 24-28 MPa reported by Brown et al. (2006), although it is acknowledged that concrete stiffness is dependent on the mix design and the aggregate type. Piles were consistently tested $24 \mathrm{~h}$ after casting. The model CHD piles were all approximately $400 \mathrm{~mm}$ long, resulting in a length/flange diameter ratio of $6 \cdot 6$, which is greater than the minimum $L / D$ ratio considered for deep foundation pile end bearing behaviour by Berezantzev et al. (1961). The helical nature of the piles formed is shown in Figure 4. Further details of the model CHD pile formation equipment and the techniques used are given by Jeffrey (2012).

In order to evaluate CHD pile performance during load testing, six pairs of $120 \Omega$ strain gauges were installed in a number of completed CHD piles. The strain gauges were attached at equal distances along a roughened $10 \mathrm{~mm}$ diameter aluminium rod ( $80 \mathrm{~mm}$ spacing between gauges) inserted into the centre of a freshly cast CHD pile. Aluminium was chosen for its relatively low modulus of $70 \mathrm{MPa}$ compared with steel, which increases the sensitivity of the rod to strains in the pile. The diameter of the aluminium rod was minimised such that it had an axial stiffness three orders of magnitude lower than the concrete pile to minimise inclusion effects while still allowing strain gauge application. The uppermost strain gauge (gauge 6) was located approximately $40 \mathrm{~mm}$ above the mean adjacent sand surface. The lowest strain gauge (gauge 1) was approximately $30 \mathrm{~mm}$ above the tip of the CHD pile. The gauges measured axial strain within the pile when load testing was carried out and were used to determine the axial load distribution as outlined by Brown et al. (2006) and Jeffrey (2012). Typical axial load distribution curves for the model CHD pile at increasing pile settlements (normalised by pile diameter $D$, or $D_{\mathrm{f}}$ in the case of the CHD pile) under axial compressive load are presented in Figure 5. An average pile area was used to determine the axial load distribution using the effective pile diameter $D_{\mathrm{e}}$ (Figure 2).

\subsection{Formation of jacked and WIP piles}

The CHD piles were compared with both displacement and non-displacement model piles. This was achieved by installing jacked (pushed-in-place, displacement pile) or WIP (nondisplacement pile) piles. Both the jacked and WIP piles were precast in plastic moulds using the same grout used to form the CHD piles. For the jacked piles, a smooth grout surface was left to simulate a sand-precast concrete interface by giving a light coating of de-bonding agent to the mould surface. For the WIP piles, a rough surface was created by using epoxy resin to glue a layer of sand onto the surface of the cast pile so as to replicate the rough failure interface typical of cast in situ piles. Both the jacked and WIP piles incorporated a Novatech cylindrical tension/compression load cell $(25 \mathrm{kN})$ held within a cylindrical housing unit that could be cast permanently into either pile type to measure base load (further details are given

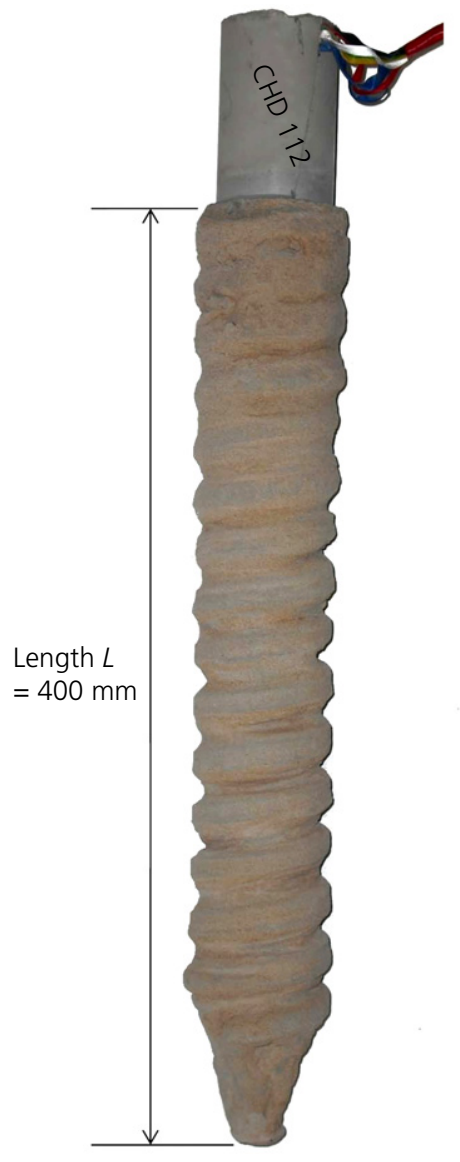

(a)

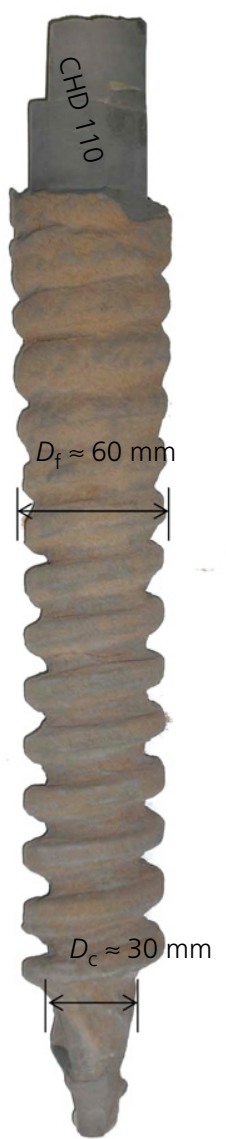

(b)
Figure 4. Typical examples of exhumed model CHD piles formed in (a) loose sand (CHD 112) and (b) dense sand (CHD 110)

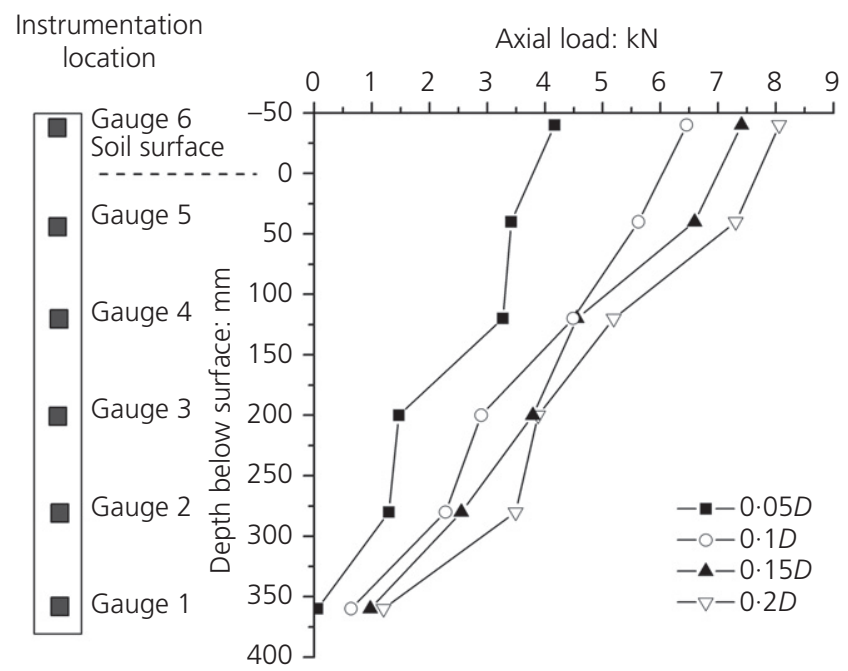

Figure 5. Load distribution down the CHD pile at increasing levels of pile settlement (dense sand) 


\begin{tabular}{|c|c|c|c|c|c|}
\hline \multirow[t]{2}{*}{ Pile type } & \multirow[t]{2}{*}{$\begin{array}{c}\text { Number of tests } \\
\text { undertaken }\end{array}$} & \multirow[t]{2}{*}{ Interface type } & \multirow[t]{2}{*}{$\begin{array}{l}\text { Ultimate interface } \\
\text { friction angles, } \delta_{\text {crit: }} \text { degrees }\end{array}$} & \multicolumn{2}{|c|}{$\begin{array}{c}\text { Average peak interface friction } \\
\text { angle, } \delta_{\mathrm{p}} \text { : degrees }\end{array}$} \\
\hline & & & & $\sigma_{\mathrm{n}}=1-5 \mathrm{kPa}$ & $\sigma_{\mathrm{n}}=10-15 \mathrm{kPa}$ \\
\hline $\mathrm{CHD}$ & 22 & Sand-sand & 32 & $42 \cdot 7+0 \cdot 2 D_{r}$ & $32 \cdot 4+0 \cdot 2 D_{r}$ \\
\hline Jacked & 9 & Sand-sand-roughened grout & 26 & $39 \cdot 1+0 \cdot 2 D_{r}$ & - \\
\hline WIP & 9 & Sand-smooth grout & 24 & $36 \cdot 1+0 \cdot 1 D_{r}$ & - \\
\hline
\end{tabular}

Table 1. Peak and critical state friction angles for sand used in model tests at low effective stress

by Jeffrey (2012)). Total applied load at the pile head was measured using the Instron 1196 with shaft friction determined from the difference between the two load cell readings.

The jacked piles were installed by first clamping them in the Instron and then advancing to the same depth as CHD pile installation at a constant rate of $20 \mathrm{~mm} / \mathrm{min}$. The WIP piles were formed by first pluviating sand at the appropriate relative density to the elevation of the pile tip. The pile was then carefully suspended at its head from a single arm clamped to the top of the box such that the pile hung above the sand with the tip just in contact with the existing sand. Pluviation was then completed up to the required surface level around the suspended pile.

\subsection{Interface properties}

Direct shear box tests were undertaken using a standard $60 \mathrm{~mm}$ square shear box conforming to BS 1377 (BSI, 1990) on dry sand-sand samples. Similar testing was undertaken for the sand-grout interfaces, in which the lower half of the shear box was replaced by a block of grout prepared with surface roughness similar to that of the precast piles. Due to the nature of the $1 \mathrm{~g}$ model tests, the effective stresses experienced in the test beds were much lower than those expected in the field. To account for this, the tests were conducted over two effective normal stress ranges, these being $\sigma_{\mathrm{n}}=1-5 \mathrm{kPa}$ (to reflect stress levels over the model shaft length) and $\sigma_{\mathrm{n}}=10-15 \mathrm{kPa}$ (stress levels at the pile tip), at three relative densities $\left(D_{\mathrm{r}}\right)$ selected to mimic those used during the model pile tests. Sand samples were sheared at a constant rate of $1.2 \mathrm{~mm} / \mathrm{min}$. Results from the shear box tests are shown in Table 1 . The increased dilation noted at low effective stresses $(1-10 \mathrm{kPa})$, associated with the pile shaft stress levels, is consistent with previous results on the same sand (e.g. Lauder and Brown, 2014; Lauder et al., 2013). All shear box tests were corrected for friction due to the nature of the low shear stresses generated at low normal stresses.

\subsection{Model pile load testing}

Load testing of all the model piles was performed using the same Instron load frame used during installation. The piles were loaded in axial compression by applying a constant rate of penetration of $2 \mathrm{~mm} / \mathrm{min}$, within the ranges specified in BS EN 1997-1:2004 (Brown, 2012). In order to reduce stress on the pile head and ensure even load distribution, a steel loading cap was fabricated and placed over the head of the pile immediately after pouring.

\section{Results}

\subsection{Effective diameter investigation}

An important factor in being able to design a CHD pile is the selection of an appropriate design diameter, given the complex shape. The load-settlement behaviour of the CHD pile was therefore compared with those of the simulated traditional installation methods. Two different diameters were tested for both jacked and WIP pile types, representing the model CHD pile inner core $D_{\mathrm{c}}(30 \mathrm{~mm})$ and outer flange $D_{\mathrm{f}}(60 \mathrm{~mm})$ diameters; these were installed to the same depth as the CHD piles. The load-settlement behaviour for each pile type at the different relative densities considered is shown in Figure 6.

The ultimate load capacity was defined in this work at a settlement $w=10 \%$ of the pile diameter $\left(D_{\mathrm{f}}\right.$ in the case of the CHD piles). This definition is routinely used in load testing smallscale piles (Gavin and O'Kelly, 2007; White and Zhao, 2006). From Figure 6, the same general trends in relative performance between the different pile types can be seen across the different densities of soil. The CHD and jacked piles $\left(D=D_{\mathrm{f}}\right)$ can be seen to outperform the core and flange diameter WIP piles in terms of ultimate load capacity and initial stiffness at all densities, which strongly suggests that the CHD pile installation process results in either soil improvement or enhanced roughness along the shaft (at the macro scale due to the ribbed profile) or a combination of the two effects. It is interesting to note that the CHD pile capacity in medium dense sand (Figure 6(b)) was approximately double that of the $D_{\mathrm{f}}$ WIP pile; this compares with an approximate increase of 1.67 witnessed by Busch et al. (2010) between an auger displacement pile and a bored pile installed in medium dense sand. Similarly, Katzenbach and Schmitt (2005) showed a doubling of shaft resistance for a screw pile compared with the performance of a similar CFA pile through FEM simulation. It is also evident that the CHD pile has a greater ultimate capacity and 

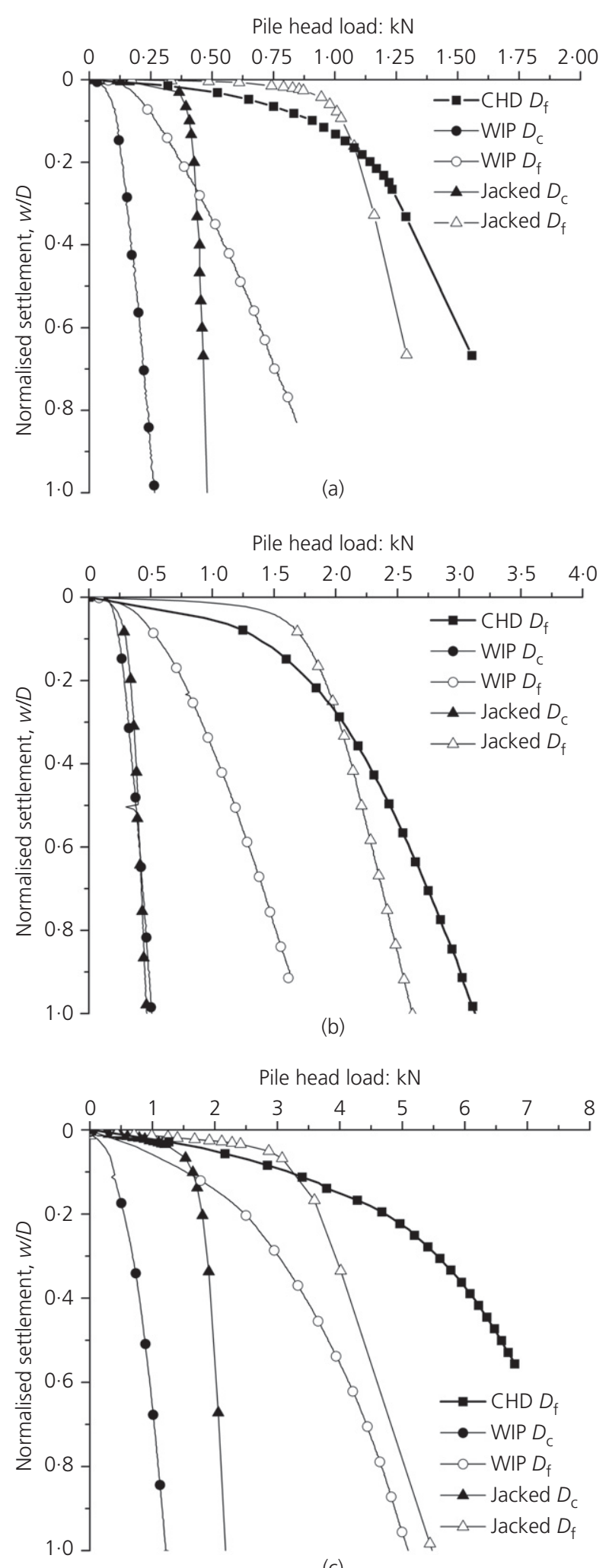

(c)

Figure 6. Comparison of CHD pile load tests with jacked and WIP piles of different diameters installed in: (a) loose sand $\left(D_{\mathrm{r}}=22 \%\right)$; (b) medium dense sand ( $\left.D_{\mathrm{r}}=49 \%\right)$; (c) dense sand ( $D_{\mathrm{r}}=78 \%$ ) superior stiffness to the core diameter jacked pile for all states of relative density. The ultimate load capacities of the CHD piles (at $0 \cdot 1 D_{\mathrm{f}}$ ) are close to those of the flange diameter jacked piles, and are clearly larger for $w>0 \cdot 1 D_{\mathrm{f}}$. These observations would tend to support the use of the full flange diameter in the analytical capacity determination of CHD piles (i.e. $D_{\mathrm{e}}=D_{\mathrm{f}}$ ) rather than the average of the core and flange diameters used currently.

The CHD piles showed a lower initial stiffness prior to failure $\left(w / D_{\mathrm{f}}<0 \cdot 1\right)$ than the flange diameter jacked piles, but improved stiffness compared with the other pile types tested. After the load tests were completed, the model CHD piles were carefully exhumed from the test bed. This revealed that the model CHD pile visually resembled a large-diameter straight-shafted pile rather than a helical screw pile; upon closer inspection of the piles, it was found that sand was tightly wedged or trapped in the gaps between the flanges (Figure 7). The pile shown in Figure 7 was installed in dense sand, but similar behaviour was observed for the piles tested in other sand densities. The trapped sand between the flanges had the effect of creating a pile with a diameter approximately equal to the flange diameter, resulting in a predominantly sand-sand interface mechanism along the shaft. This finding is also supported by the common design assumption used for full-scale design where the interface friction angle $\delta^{\prime}$ is taken as the soil-soil friction angle $\phi^{\prime}$ (Bell, 2010).

\subsection{Radial effects of pile installation}

Installation of the CHD piles appeared to cause predominantly lateral displacement of soil, similar to that observed by Hird et al. (2011) and Busch et al. (2010). Physical modelling of the installation of screw piles in transparent soil (Hird et al., 2011) showed that soil is carried by the flights away from the auger tip and forced laterally outwards around the main body of the auger before returning back towards the auger stem. Therefore, it would appear to be important to determine the influence of these radial installation effects on the surrounding soil. This is important not only for determining how they affect the performance of the CHD pile, but may also be important in subsequent consideration of group effects or the influence on adjacent buildings for such piles.

In an attempt to monitor this during the model tests, the effect of pile installation was determined using a $16 \mathrm{~mm}$ diameter model CPT probe (as developed by Jeffrey (2012)) in a similar manner to that proposed by Katzenbach and Schmitt (2005). Cone resistances were measured $24 \mathrm{~h}$ after installation at increasing radial distances from the centre of the installed piles equal to $1 D, 1 \cdot 5 D, 2 D$ and $3 \cdot 3 D$ where $D$ is the outer diameter of the installed pile. CPTs were arranged around the pile to minimise interference between tests such that each test had uninterrupted 'line of sight' to the pile (Jeffrey, 2012). Cone resistance variations due to installation of the piles in loose, medium dense and dense sand are shown in Figure 8. In this 


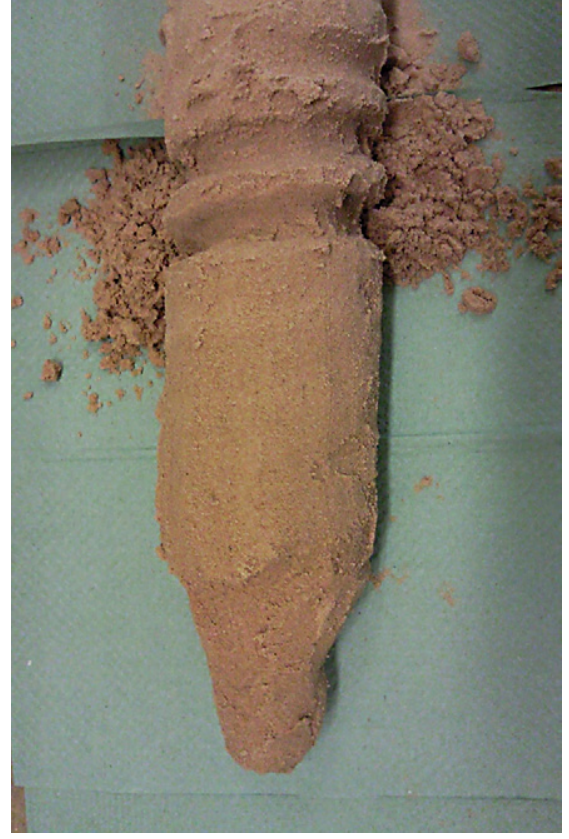

(a)

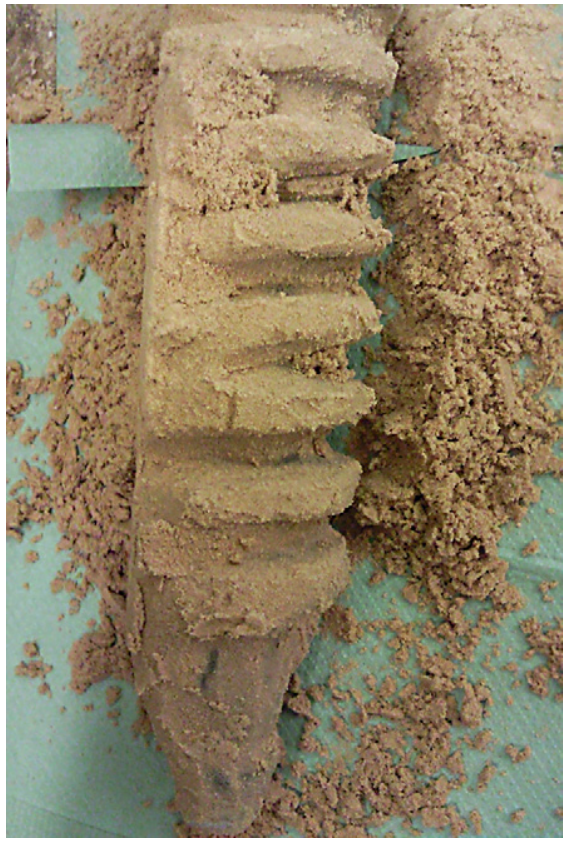

(b)

Figure 7. Images of exhumed CHD piles after load testing in dense sand (a) immediately after exhumation with some sand removed to upper section of pile and (b) following careful removal of trapped sand

figure, the cone resistance is normalised using the 'free-field' cone resistance $3 \cdot 3 D$ away from the pile base $\left(q_{\mathrm{c} 3 \cdot 3 D}\right)$ as it was found that the CPT carried out at this distance provided measurements equivalent to those in virgin soil, which is consistent with the findings of Katzenbach and Schmitt (2005). The penetration depth of the CPT probe $\left(z_{\mathrm{CPT}}\right)$ is normalised using the embedded length of the pile $(L)$. In Figure 8, a $q_{\mathrm{c}} / q_{\mathrm{c} 3 \cdot 3 D}$ value greater than 1 is interpreted as an apparent densification of the sand compared with free-field conditions, while a value lower than 1 is interpreted as an apparent loosening of the soil, following the approach adopted by Katzenbach and Schmitt (2005). This is as a result of the shearing of the soil around piles during installation of displacement-type piles, resulting in predominantly contraction of loose soils (apparent densification) and dilation of denser soils (apparent loosening). Cone penetration in the dense sand (Figure 8(c)) was not conducted to the same depth as in the other densities as the loads experienced on the CPT tip load cell had reached the safe working limit and penetration was thus stopped. In most instances, penetration of the CPT managed to equal or exceed the installation depth of the pile.

Figure 8 shows that installation of the CHD pile clearly had an influence on the in situ soil conditions, although the amount of influence varied depending on the relative density of the sand. When installed in loose sand, the CHD pile can be seen to cause apparent densification (Figure 8(a)). As the initial in situ density of the sand bed increases, CHD pile installation tends to cause both apparent loosening and densification, depending on the depth of penetration. As can be seen in Figure 8(b), the radial increase in CPT cone resistance in the model piles is similar to that shown at a distance $1 D$ away from a full-scale auger displacement pile installed in medium dense sand (Busch et al., 2010). The variation with depth is also relatively similar but direct comparison is complicated due the complexity of the field stratigraphy (i.e. nearsurface made ground and an organic silt layer part way down the profile in the case of the field data reported by Busch et al. (2010)). However, the profile is consistent with that predicted by Katzenbach and Schmitt (2005) who reported a significant increase in pile shaft capacity in the lower section of the pile.

It is also apparent from Figure 8 that CHD pile installation appears to affect the soil to a greater radial extent than the jacked piles. This may be as a result of the CHD bullet passing through the soil twice during pile formation and/or over-pressurisation of the injected grout used to form the CHD pile. The grouting pressure used in pile formation was determined by trial and error to allow the formation of a consistent pile crosssection (rather than an attempt to match in situ conditions). A comparison with field grouting pressures is difficult as these are not measured directly in the field, with pump hydraulic 


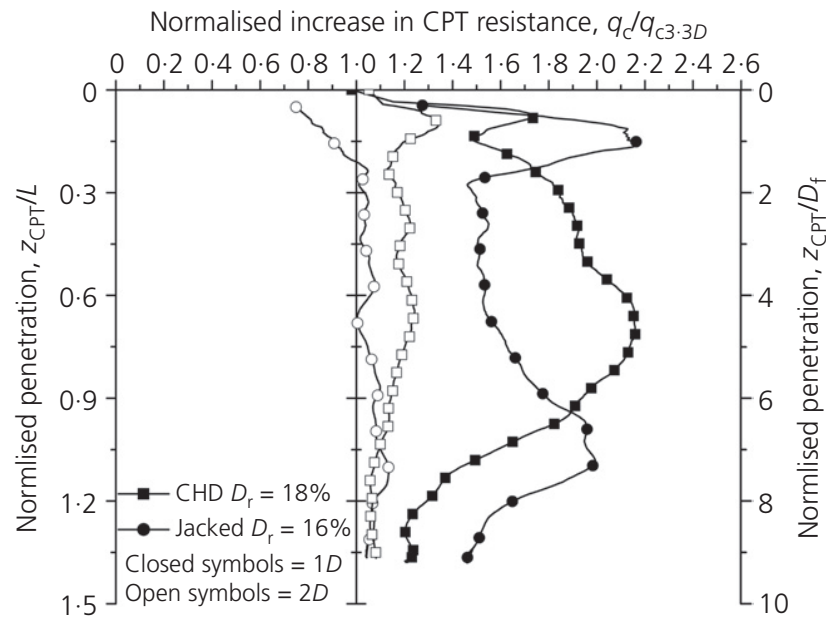

(a)

Normalised increase in CPT resistance, $q_{\mathrm{C}} / q_{\mathrm{C} 3 \cdot 3 \mathrm{D}}$

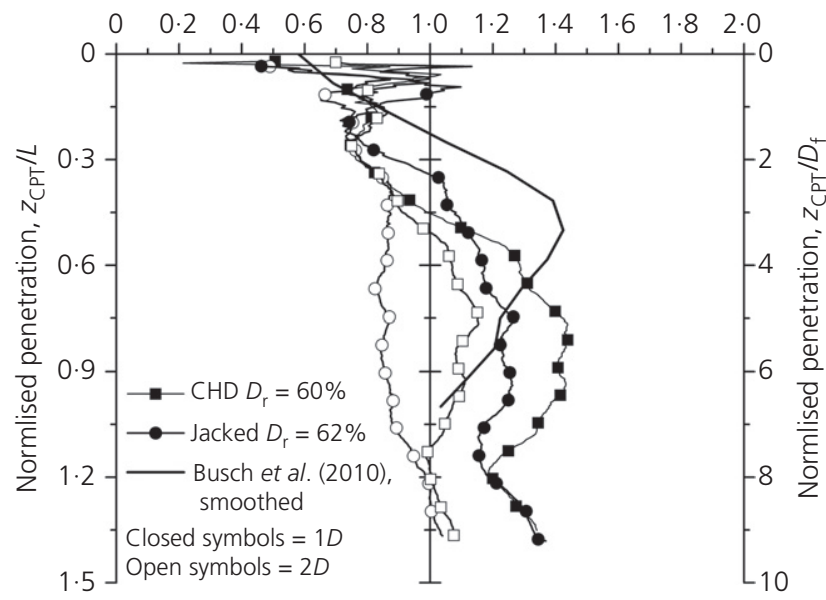

(b)

Normalised increase in CPT resistance, $q_{\mathrm{C}} / q_{\mathrm{C} 3 \cdot 3 \mathrm{D}}$

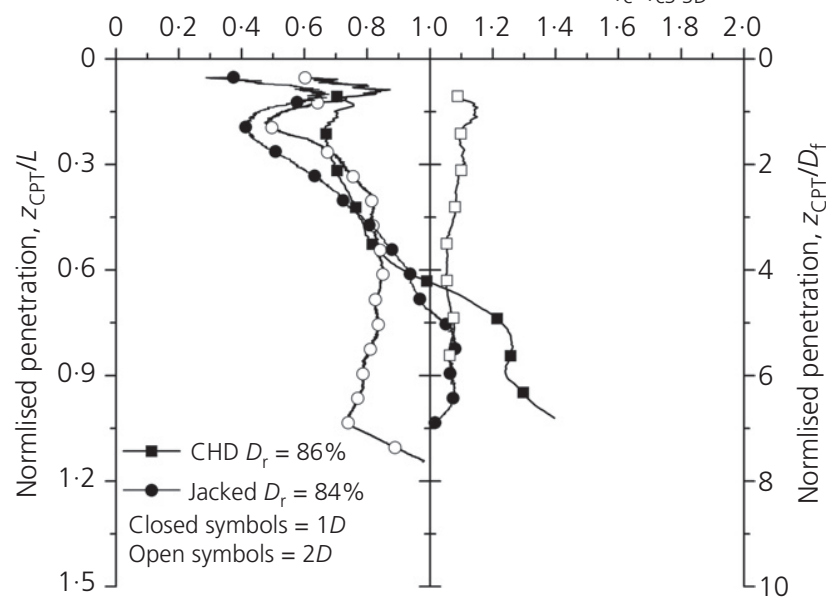

(c)

Figure 8. Comparison of variation of cone resistance at various radial positions away from installed $\mathrm{CHD}$ and jacked piles:

(a) loose sand; (b) medium dense sand; (c) dense sand

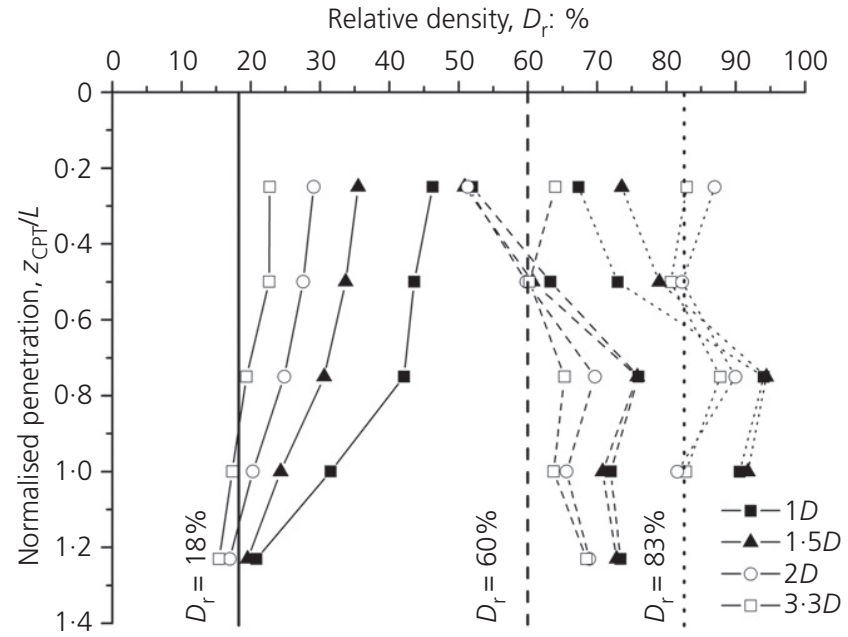

Figure 9. Changes in relative density due to the installation of model CHD piles determined using CPT measurements

pressures monitored rather than concrete pressures. Grout pressures were typically reduced slightly on the bullet nearing the surface to avoid blow out or oversized near-surface sections. This is an operation that occurs in the formation of fullscale piles.

Using cone resistances from calibration test beds (of known relative density), the relative density prediction approach from cone resistance measurements proposed by Jamiolkowski et al. (1985) was calibrated for the HST95 sand (Jeffrey, 2012). It was then possible to estimate the apparent relative density of the sand in the CHD pile test bed using the measured CPT cone resistances. In Figure 9, the effect of the CHD pile installation can be seen to cause, on average, a doubling of the undisturbed relative density (from $18 \%$ to an average of $40 \%$ ) at a radial distance of one diameter in loose sand. In medium dense sand, the influence of CHD pile installation on the apparent relative density can be seen to vary with pile penetration depth. A reduction in relative density from $60 \%$ to approximately $52 \%$ is evident at approximately $0 \cdot 3 L\left(2 D_{\mathrm{f}}\right)$ with an increase to in situ conditions by $0 \cdot 5 L\left(3 \cdot 3 D_{\mathrm{f}}\right)$. Between a depth of $0 \cdot 5 L\left(3 \cdot 3 D_{\mathrm{f}}\right)$ and $1 L\left(6 \cdot 6 D_{\mathrm{f}}\right)$, pile installation is seen to increase the relative density to $75 \%$ from $60 \%$. Around the toe of the pile, the increase in relative density, to approximately $72 \%$ from $60 \%$, occurs down to a depth of $1 \cdot 2 L\left(8 D_{\mathrm{f}}\right)$. This apparent improvement towards the lower sections of the pile is consistent with the observations of Katzenbach and Schmitt (2005), as previously noted. For dense sand, pile installation is again seen to cause a slight loosening of the soil from $D_{\mathrm{r}}=83 \%$ to an average $D_{\mathrm{r}}=70 \%$ near the surface to a depth of $0 \cdot 5 \mathrm{~L}\left(3 \cdot 3 D_{\mathrm{f}}\right)$. At depths greater than $0 \cdot 5 \mathrm{~L}\left(3 \cdot 3 D_{\mathrm{f}}\right)$ there is a slight apparent densification of up to $D_{\mathrm{r}}=92 \%$, a significantly lower comparative increase than that found in loose or medium dense sands. On average, the apparent relative density 
Load: kN

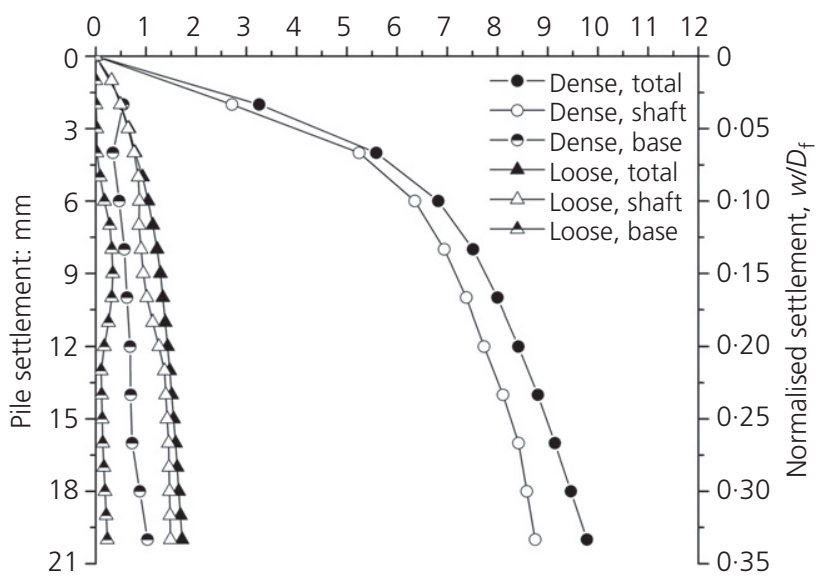

Figure 10. Load-settlement curves for model CHD piles with base and shaft responses shown for loose and dense sand cases

change caused by the CHD pile installation in dense sands is minimal compared with the initial density.

Although the measured change in CPT resistance has been directly correlated with a change in density, it is noted that this an over-simplification and is used here as an indicator of the changes that occur during installation due to shearing and subsequent density change and stress increase due to the cavity expansion-type process being undertaken. The results of CPTs will also be influenced by the presence of a rigid pile inclusion, which will lead to increased cone end bearing resistance, an over-prediction of the apparent degree of densification and an under-prediction of the apparent loosening.

\subsection{CHD pile load distribution}

The shaft-base load split is seen to vary depending on the in situ soil density, as can be seen in Figure 10. At a displacement equal to $0 \cdot 1 D_{\mathrm{f}}(6 \mathrm{~mm}$, ultimate capacity), in loose sand, the shaft resistance is seen to provide approximately $73 \%$ of the ultimate capacity at large settlements. For piles installed in dense sand, the shaft resistance provides much of the initial capacity up to settlements of $0 \cdot 05 D_{\mathrm{f}}$. The shaft capacity for the model CHD pile in dense sand typically contributes $90 \%$ of the ultimate capacity at settlements greater than $0 \cdot 1 D$.

\subsection{Installation torque}

During installation and formation of the CHD piles, the torque exerted on the bullet and shaft was measured using an inline transducer. The ability to gain an understanding of the soil conditions during pile installation could be used to give an indication of the resulting pile's capacity prior to load testing. Such insights may be beneficial to site practice in terms of verification of design assumptions or allow an observational approach to pile length requirements. Figure 11 shows that

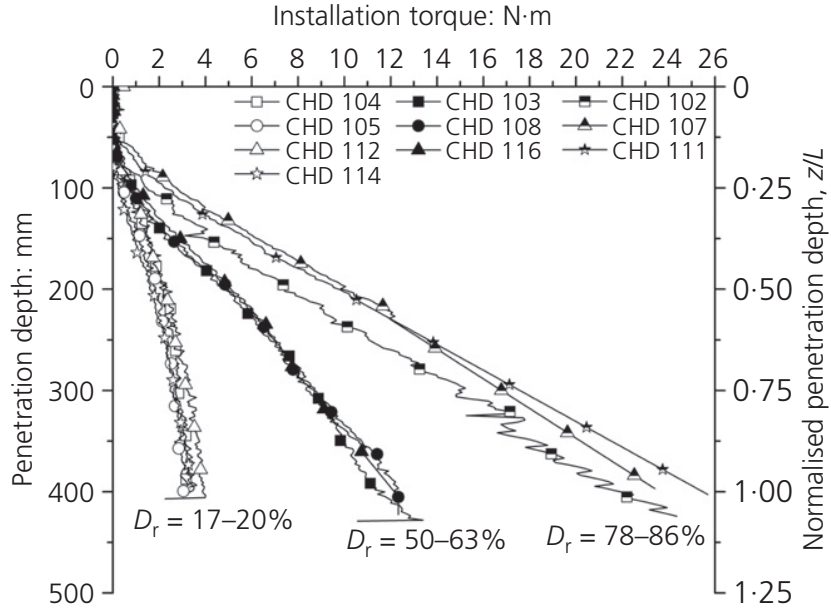

Figure 11. Installation torque required for $\mathrm{CHD}$ bullet penetration in sands (CHD 102-CHD 116) at different relative densities

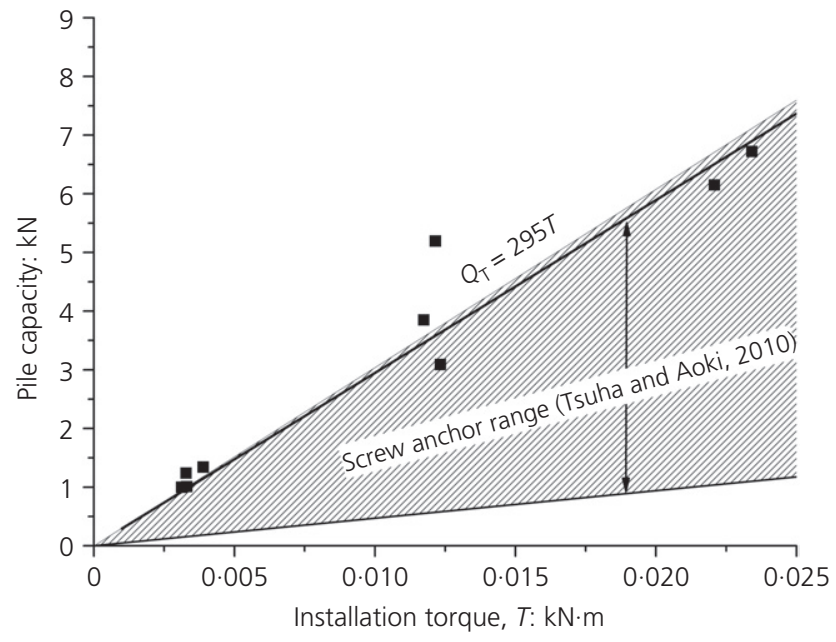

Figure 12. Relationship between installation torque and CHD pile capacity

there is a clear relationship between the in situ relative density and the required installation torque, with greater torque indicating denser soil.

For CHD piles, the installation torque increases linearly with penetration depth once the bullet has fully penetrated the soil (at $80 \mathrm{~mm}$ penetration). The required torque at a specific penetration depth increases with relative density in a similar manner to the model CFA piles studied by Kenny et al. (2003). The average installation torque varies with the ultimate pile capacity, with an average correlation of $Q_{\mathrm{T}}=295 T$ (Figure 12) in which $T$ is the measured torque. This factor lies towards the upper values of those reported by Tsuha and Aoki (2010) for small-diameter model helical screw anchors $\left(Q_{\mathrm{T}}=47-304 T\right)$. 


\section{Proposed analytical design approach for compressive vertical CHD pile capacity}

It has already been noted that the instrumentation of the model piles allows separation of the base resistance $\left(Q_{\mathrm{b}}\right)$ and the shaft resistance $\left(Q_{\mathrm{s}}\right)$. Effective stress design procedures used in pile design can be found in various published works, but Fleming et al. (2009) suggest the following expressions for base and shaft components in coarse-grained soils

1. $Q_{\mathrm{b}}=N_{\mathrm{q}} \sigma_{\mathrm{v}}^{\prime}(L) A_{\mathrm{b}}$

$$
\text { 2. } Q_{\mathrm{s}}=\int_{\text {Pile length }}\left[K \sigma_{\mathrm{v}}^{\prime}(z) \tan \delta^{\prime}\right] \mathrm{d} A_{\mathrm{s}}
$$

where $N_{\mathrm{q}}$ is the bearing capacity factor, $\sigma_{\mathrm{v}}^{\prime}$ is the vertical effective stress, $A_{\mathrm{b}}$ and $A_{\mathrm{s}}$ are the area of the base and shaft, respectively, $K$ is the lateral earth pressure coefficient and $\delta^{\prime}$ is the interface friction angle. As previously mentioned, the current approach to CHD pile design is to use the full flight diameter $\left(D_{\mathrm{f}}\right)$ to determine the base area similar to a flatended pile, while the shaft area is assumed to be as per a straight-shafted pile with a diameter equal to the effective diameter $D_{\mathrm{e}}$ (see Figure 2) and the length of the pile is assumed to be the maximum depth of bullet insertion. This latter assumption may appear non-conservative based upon the tapered shape at the end of the CHD pile but this is adopted due to uncertainties over the final shape of the pile toe for piles installed in the field (as very few have been exhumed).

Traditionally, the bearing capacity factor $N_{\mathrm{q}}$ may be taken from the values suggested by Berezantzev et al. (1961), which were determined using the angle of friction of the in situ soil. It should be noted that, in this analysis, the apparent densification effects have been ignored (i.e. in situ density prior to pile installation was used for determination of appropriate peak friction angles). Using the measured base capacity for jacked and WIP piles, or that derived from pile instrumentation in the case of CHD piles, $N_{\mathrm{q}}$ can be back-calculated for each type of model pile. Figure 13(a) shows the derived $N_{\mathrm{q}}$ values for various pile types compared with the relationship proposed by Berezantzev et al. (1961). The results were plotted using the peak friction angles at the appropriate relative density for each test using the results from shear box testing over the range $10-15 \mathrm{kPa}$, which is consistent with the model stress range at tip level (Table 1). It is clear that the $N_{\mathrm{q}}$ values for all pile types determined from the model testing using peak friction angles fall below those determined by Berezantzev et al. (1961). It should also be noted that Berezantzev et al. (1961) only show data up to $40^{\circ}$; their relationship has been assumed to relate to peak friction angles (this is not stated explicitly but they refer to dense samples) determined using stress levels more commonly adopted in shear box testing (100-800 kPa)

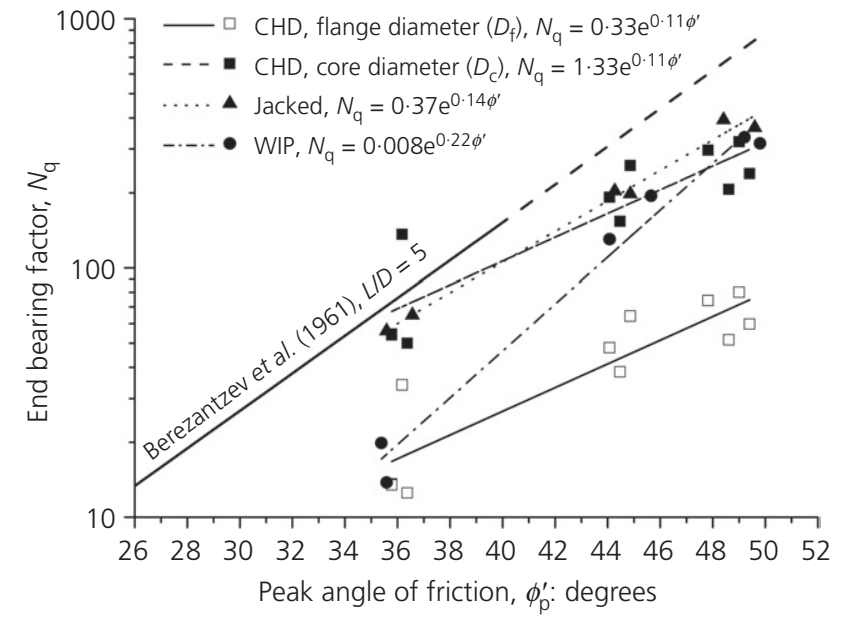

(a)

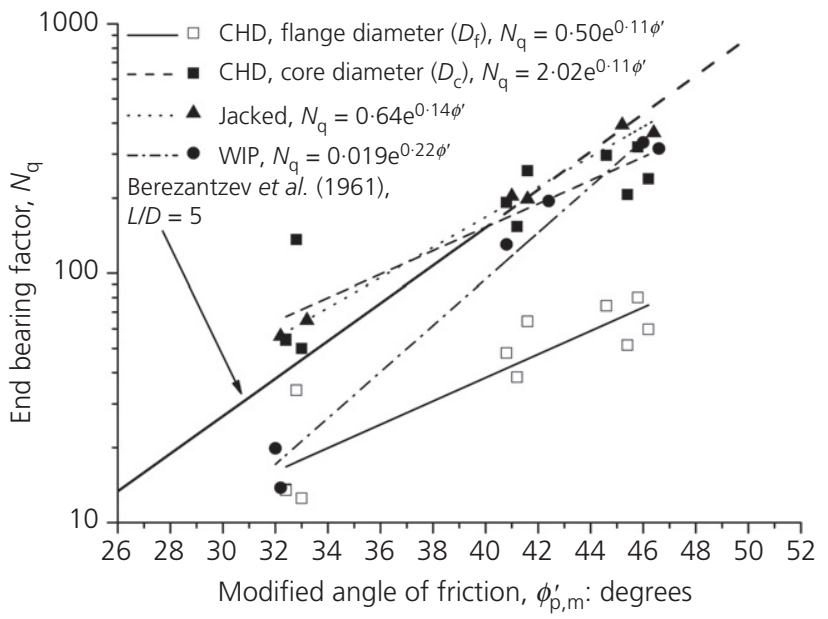

(b)

Figure 13. Relationship between end bearing capacity factors and (a) peak friction angle and (b) corrected peak friction angle for model piles

for standard characterisation of soils for full-scale field studies and that the relationship extrapolates to higher friction angles as shown in Figure 13(a). Such an approach does not allow ease of comparison with $1 \mathrm{~g}$ model tests where effective stresses may be one to two orders of magnitude lower where significant dilation and higher resulting peak friction angles may occur (Lauder and Brown, 2014). For comparison, therefore, in Figure 13(b) the data from the model tests are shown plotted against a lower peak friction angle, reflecting the range of effective stresses assumed to have been used by Berezantzev et al. (1961). This modification is based upon the relationship proposed by Al-Defae et al. (2013) drawn from 38 tests in HST95 sand at different relative densities covering effective stresses from $5 \mathrm{kPa}$ to $200 \mathrm{kPa}$ where $\phi_{\mathrm{p}, \mathrm{m}}^{\prime}=20 D_{\mathrm{r}}+29^{\circ}$ (note the similarity of this relationship to the $10-15 \mathrm{kPa}$ data in Table 1). This results in $N_{\mathrm{q}}$ values for the jacked piles similar to those proposed by Berezantzev et al. (1961). 
Figure 13 shows results for the CHD pile $N_{\mathrm{q}}$ values calculated using both the pile flange diameter $D_{\mathrm{f}}$ and the core diameter $D_{\text {c }}$. Using the core diameter seems to give the best comparison with the work of Berezantzev et al. (1961) and the jacked pile data. The $L / D$ ratio for the model piles was $6 \cdot 6$, thus the similarity to Berezantzev et al. (1961) is notable. This similarity in behaviour and that shown in Figure 6 would suggest that, in analysis of a field-scale pile, where the full length of the pile (to the bullet tip) is used for shaft calculation, the end bearing resistance should be determined using $N_{\mathrm{q}}$ values given by

\section{3. $N_{\mathrm{q}}=1 \cdot 33 \mathrm{e}^{0 \cdot 11 \phi_{\mathrm{p}}}$}

with the base diameter taken as the core diameter of the pile. Although the results for CHD and jacked piles are similar to those reported by Berezantzev et al. (1961) especially when the difference in $L / D$ is noted, it is apparent that using the approach of Berezantzev et al. (1961) becomes less suitable for WIP piles with reducing sand density. This is not unexpected, as non-displacement piles typically mobilise full base resistance at larger settlements compared with displacement pile types.

For determination of the pile shaft resistance, the earth pressure coefficient suggested by Fleming et al. (2009) ranges from 0.9 for bored piles to 1.2 for displacement piles. Bell (2010) suggests typical design values varying between 1.0 and 1.2 for similar full-displacement cast in situ piles with $\delta^{\prime}=\phi^{\prime}$. Unfortunately, these suggested values give little regard to in situ soil conditions, unlike the values recommended by Meyerhof (1976) who suggests that $K$ varies with the in situ peak angle of friction for both driven and bored piles. Figure 14 shows back-calculated $K$ values for the model piles $\left(D=D_{\mathrm{f}}\right.$ and $\delta^{\prime}=\phi_{\mathrm{p}}^{\prime}$ in the case of the CHD piles) compared with measured $K$ values from field studies on various pile types (Bell, 2010; Meyerhof, 1976). The results are also compared with $K-\phi^{\prime}$ relationships from the literature, derived from the uplift capacity of screw anchors at large $L / D$ ratios (i.e. deep mechanism), extrapolated past the original data set (using higher values of friction angle). Again, consideration has to be given to the large peak friction angles generated in the sand around the model pile, especially where in situ effective stresses are very low over the length of the pile shaft. The impact of this dilation is significant, resulting in relatively large $K$ values for the derived shaft resistance (Figure 14) although it should be noted that Bell (2010) reported $K$ values in excess of 4 derived from field testing of full-scale auger displacement piles installed in medium dense very sandy gravel. Results for the WIP and jacked piles compared with the respective field pile results for driven, jacked and bored piles from Meyerhof (1976) suggest that use of the actual peak friction angles in the model is appropriate and that the proximity of the test box boundaries does not significantly affect the $K$ values. The $K$ value for the jacked and driven field piles seems to be captured well by the relationship proposed by Mitsch and Clemence (1985), which was determined for screw anchor uplift

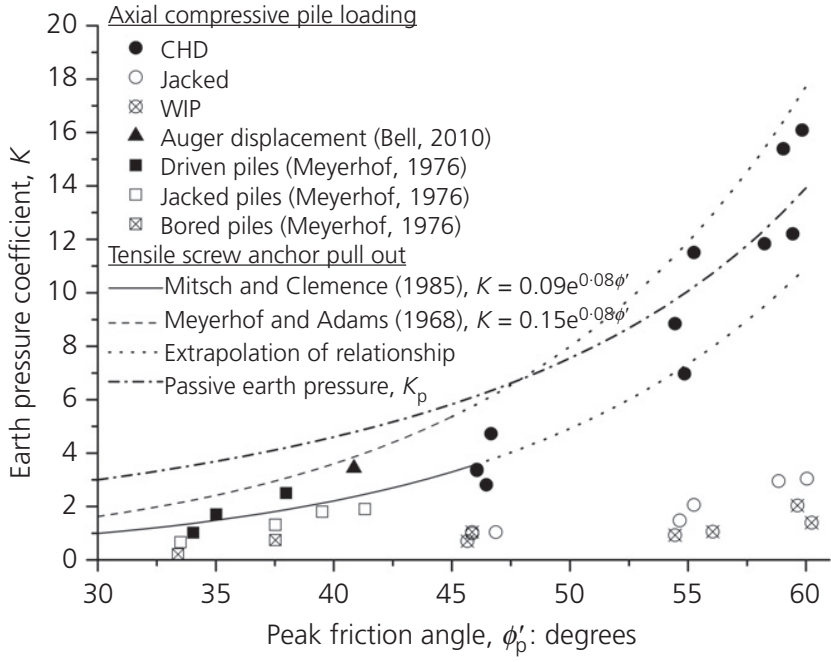

Figure 14. Relationship between the earth pressure coefficient for pile shaft determination and peak friction angle for the model piles compared with other model and field study results

in sand based on both field and laboratory model testing. Extrapolating this relationship and that proposed by Meyerhof and Adams (1968) to higher friction angles, associated with the soil-soil shear mode of the CHD piles, appears to capture the model CHD pile response, with the Meyerhof and Adams (1968) relationship acting as the upper bound and the relationship of Mitsch and Clemence (1985) as the lower bound. In contrast to the Mitsch and Clemence (1985) relationship, the approach of Meyerhof and Adams (1968) is based predominantly on the uplift of plane strain buried model plates. Mitsch and Clemence (1985) proposed that the difference between the two studies is due to lack of disturbance in the model plate tests, which did not simulate the plate anchor installation process and soil disturbance. To some extent, this explanation seems at odds with the CHD pile behaviour where the installation process seems to enhance the capacity. Thus, for design purposes the following relationship, proposed by Mitsch and Clemence (1985), is suggested to predict a conservative $K$ value

\section{4. $K=0.09 \mathrm{e}^{0.08 \phi_{\mathrm{p}}}$}

This relationship should be associated with use of the full flange diameter in determining the shaft resistance but should be limited to the range of previous field study friction angles consistent with the research by Meyerhof (1976) and Bell (2010) (i.e. not exceeding $42^{\circ}$ ).

In order to verify the suggestion of using Equations 3 and 4 for design purposes, measured results of total model pile resistance were compared with that predicted by Equations 3 and 4 for all of the pile tests considered in this study. The results, shown in Figure 15, clearly indicate that at lower relative densities (where 


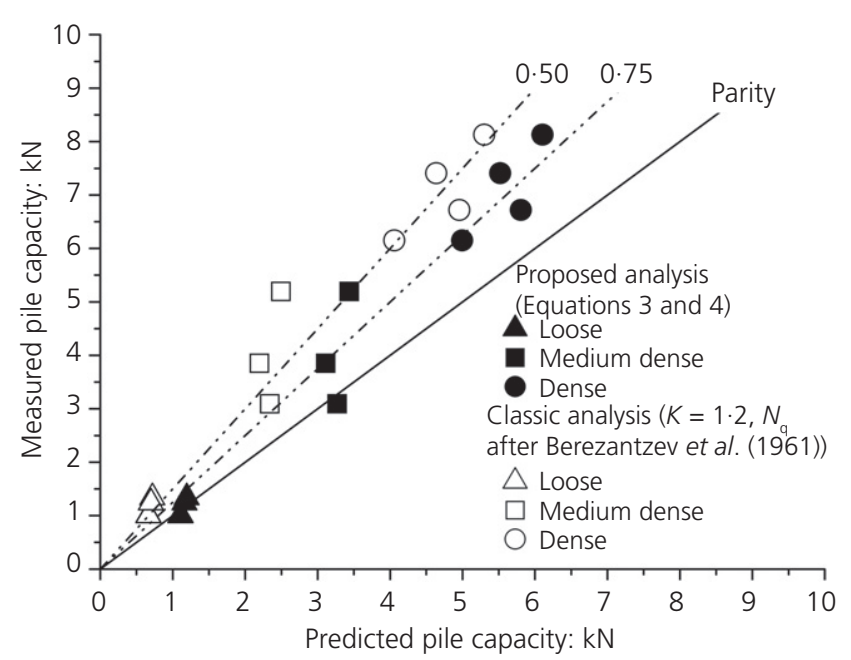

Figure 15. Comparison of predicted and measured model pile capacity based upon the proposed relationships for CHD pile lateral earth pressure coefficient and bearing capacity factor

pile resistance is lower) the proposed prediction approach works well. At higher relative densities the proposed approach tends to under-predict pile capacity by an average of $25 \%$. However, it is noted from Figure 14 that the Mitsch and Clemence (1985) relationship under-predicts the majority of $K$ values and its use has been proposed as a lower bound safe approach for the design of full-scale piles where such high friction angles (associated with the model study) would not be encountered. Figure 15 also shows the prediction of model pile behaviour based on existing design approaches based on $K=1.2$ and $N_{\mathrm{q}}$ determined from the paper by Berezantzev et al. (1961); this highlights the point that, although the proposed approach is conservative, it is a significant improvement over existing fixed values of $K$.

\section{Conclusions}

Based on field experience it has previously been found that the load capacity performance of continuous helical displacement (CHD) piles significantly exceeds the current design predictions in a variety of soil conditions, particularly in sands. Model testing of CHD piles was therefore carried out in order to gain a greater understanding of their performance under axial loading.

During installation of the model CHD piles, it was found that the installation results in apparent densification of the soil when the sand is loose, increasing the apparent in situ relative density by a factor of almost two. When installed in dense sand, however, some apparent densification and some apparent loosening occurred depending upon the position along the pile. This results in very little average improvement to the sand close to the pile. From comparisons with both displacement (jacked) and non-displacement (wished-in-place) pile types, the CHD pile was found to have similar axial performance - both in terms of stiffness and capacity - to a large-diameter displacement pile. This highlights that, in terms of shaft capacity determination, use of the full flange diameter of the CHD pile is more appropriate than the conservative assumption of the average of the core and flange diameters.

The authors acknowledge that the experimental set-up used here was relatively small with respect to pile-boundary separation and that the boundaries may have had a limited effect on measured pile settlements but do not appear to have influenced the back-figured lateral earth pressure coefficients.

In terms of design of the CHD pile, the issue of parameter selection for use in conventional analytical bearing capacity equations has been addressed. It has been shown that shaft capacity can be predicted using the full flange diameter and coefficient of lateral earth pressure $(K)$ values from the paper by Mitsch and Clemence (1985), selected at an appropriate peak friction angle for the confining stress level in the soil. The determination of end bearing resistance should be based on the use of the pile core diameter (reflecting the unusual shape of the CHD pile tip) and bearing capacity factor $\left(N_{\mathrm{q}}\right)$ values similar to those published by Berezantzev et al. (1961); as before, these should be determined for an appropriate peak friction angle for the confining stress level in the soil.

\section{Acknowledgments}

This research was conducted with the financial support of the Engineering and Physical Sciences Research Council (EPSRC) (funding code CASE/CAN/07/03). The authors are grateful for additional financial and technical support provided by Roger Bullivant Ltd.

\section{REFERENCES}

Al-Defae AH, Caucis K and Knappett JA (2013) Aftershocks and the whole life seismic performance of granular slopes. Géotechnique 63(14): 1230-1244, http://dx.doi.org/10.1680/ geot.12.P.149.

Bell A (2010) Foundation solutions for the urban regeneration of Glasgow city centre. In Proceedings of the DFI and EFFC 11th International Conference: Geotechnical Challenges in Urban Regeneration, London, UK. EMAP Networks, Peterborough, UK, pp. 120-129.

Berezantzev VG, Khristoforov VS and Golubkov VN (1961) Load bearing capacity and deformation of piled foundations. Proceedings of the 5th International Conference on Soil Mechanics and Foundations Engineering, Paris, France, pp. 11-15.

Bolton M, Gui M, Garnier J et al. (1999) Centrifuge cone penetration tests in sand. Géotechnique 49(4): 543-552, http://dx.doi.org/10.1680/geot.1999.49.4.543.

Brown MJ (2012) Pile capacity testing. In ICE Manual of Geotechnical Engineering, Volume II: Geotechnical Design, Construction and Verification (Burland J, Chapman T, 
Skinner H and Brown M (eds)), 1st edn. ICE Publishing, London, UK, pp. 1451-1469.

Brown MJ, Hyde AFL and Anderson WF (2006) Analysis of a rapid load test on an instrumented bored pile in clay. Géotechnique 56(9): 627-638, http://dx.doi.org/10.1680/ geot.2006.56.9.627.

BSI (1990) BS 1377:1990. Methods of test for soils for civil engineering purposes: parts 1-8. BSI, London, UK.

Busch P, Grabe J, Gerressen F and Ulrich G (2010) Use of displacement piles for reinforcement of existing pile foundations. In Proceedings of the DFI and EFFC 11th International Conference: Geotechnical Challenges in Urban Regeneration, London, UK. EMAP Networks, Peterborough, UK, pp. 113-119.

Bustamante M and Gianeselli L (1993) Design of auger displacement piles from in situ tests. In Proceedings of the 2nd International Geotechnical Seminar on Deep Foundations on Bored and Auger Piles, BAP II, Ghent, Belgium (van Impe WF (ed.)). Balkema, Rotterdam, the Netherlands, pp. 21-34.

Fleming WGF, Weltman AJ, Randolph MF and Elson WK (2009) Piling Engineering, 3rd edn. Taylor and Francis, London, UK.

Garnier J, Gaudin C, Springman SM et al. (2007) Catalogue of scaling laws and similitude questions in geotechnical centrifuge modelling. International Journal of Physical Modelling in Geotechnics 7(3): 1-23.

Gavin KG and O'Kelly BC (2007) Effect of friction fatigue on pile capacity in dense sand. ASCE Journal of Geotechnical and Geoenvironmental Engineering 133(1): 63-71.

Gavin KG, Cadogan D and Casey P (2009) Shaft capacity of continuous flight auger piles in sand. ASCE Journal of Geotechnical and Geoenvironmental Engineering 135(6): 790-798.

GCG (Geotechnical Consulting Group) (1998) CHD Pile Design Review. Confidential Report for Roger Bullivant Ltd. August 1998. Geotechnical Consulting Group, London, UK.

Grabe J, Henke S, Pucker T and Hamann T (2013) CEL: Simulations for soil plugging, screwed pile installation and deep vibration compaction. In Proceedings of International Conference on Installation Effects in Geotechnical Engineering, Rotterdam, The Netherlands (Hicks MA, Dijkstra J, Lloret-Cabot M and Karstunen M (eds)). Taylor \& Francis, London, UK (CD-ROM).

Hird CC, Ni Q and Guymer I (2011) Physical modelling of deformations around piling augers in clay. Géotechnique 61(11): 993-999, http://dx.doi.org/10.1680/geot.9.T.028.

Jamiolkowski M, Ladd CC, Germaine JT and Lancellotta R (1985) New developments in field and laboratory testing of soils. In Proceedings of the 11th International Conference on Soil Mechanics and Foundation Engineering, San Francisco, CA, USA. Taylor \& Francis, London, UK, pp. 57-153.

Jeffrey JR (2012) Investigating the Performance of Continuous Helical Displacement Piles. PhD thesis, Division of Civil Engineering, University of Dundee, Dundee, UK. See
http://discovery.dundee.ac.uk/portal/files/1229939/Jeffrey_ phd_2012.pdf.

Jeffrey JR, Schwamb T, Brown MJ and Ball J (2010)

Understanding CHD pile performance in granular soils. In Proceedings of the DFI and EFFC 11th International Conference: Geotechnical Challenges in Urban Regeneration, London, UK. EMAP Networks, Peterborough, UK, pp. 130-138.

Katzenbach R and Schmitt A (2005) Bored and screwed piles. In Proceedings of the 16th International Conference on Soil Mechanics and Geotechnical Engineering, Osaka, Japan (Adachi A (ed.)). Millpress, Rotterdam, the Netherlands, vol. 4, pp. 2129-2132.

Kenny MJ, Guasti S and Zsak P (2003) Continuous flight auger boring in sandy soils. In Proceedings of the BGA International Conference on Foundations, Dundee, UK (Newson T (ed.)). Thomas Telford, London, UK, pp. 433-441.

Knappett JA, Caucis K, Brown MJ, Jeffrey JR and Ball J (2016) CHD pile performance: part II - numerical modelling. Proceedings of the Institution of Civil Engineers Geotechnical Engineering, http://dx.doi.org/10.1680/jgeen. 15.00132.

Lauder K and Brown MJ (2014) Scaling effects in the $1 \mathrm{~g}$ modelling of offshore pipeline ploughs. In Proceedings of the 8th International Conference on Physical Modelling in Geotechnics, Perth, Western Australia (Gaudin C and White D (eds)). CRC Press, Boca Raton, FL, USA, pp. 377-383.

Lauder K, Brown MJ, Bransby MF and Boyes S (2013) The influence of incorporating a forecutter on the performance of offshore pipeline ploughs. Applied Ocean Research Journal 39: 121-130.

Meyerhof GG (1976) Bearing capacity and settlement of pile foundations. ASCE Journal of the Geotechnical Engineering Division 102(GT3): 197-228.

Meyerhof GG and Adams JI (1968) The ultimate uplift capacity of foundations. Canadian Geotechnical Journal 5(4): 225-244.

Mindess S, Young JF and Darwin D (2003) Concrete, 2nd edn. Prentice Hall, Upper Saddle River, NJ, USA.

Mitsch MP and Clemence SP (1985) The uplift capacity of helix anchors in sand. In Proceedings of the Uplift Behavior of Anchor Foundations in Soil, Detroit, MI, USA (Clemence SP (ed.)). ASCE, New York, NY, USA, pp. 26-47.

Philips R and Valsangkar AJ (1987) An Experimental Investigation of Factors Effecting Penetration Resistance in Granular Soils in Centrifuge Modelling. Cambridge University Engineering Department, Cambridge, UK, Internal report CUED/D SoilsTR210.

Randolph MF and Wroth CP (1978) Analysis of deformation of vertically loaded pile. ASCE Journal of the Geotechnical Engineering Division 104(12): 1465-1488.

Thorburn S, Greenwood DA and Fleming WGK (1993) The response of sands to construction of continuous flight 
auger piles. In Proceedings of the 2nd International Geotechnical Seminar on Deep Foundations on Bored and Auger Piles, BAP II, Ghent, Belgium (van Impe WF (ed.)). Balkema, Rotterdam, the Netherlands, pp. 429-443.

Tsuha CHC and Aoki N (2010) Relationship between installation torque and uplift capacity of deep helical piles in sand. Canadian Geotechnical Journal 47(6): 635-647.

Ueno K (2000) Methods for preparation of sand samples. In Proceedings of the International Conference Centrifuge 98, Tokyo, Japan (Kimura T, Kusakabe $\mathrm{O}$ and Takemura J (eds)). Balkema, Rotterdam, the Netherlands, pp. 1047-1055.

van Impe WF (1988) Considerations on the auger pile design. In Proceedings of the 1st International Geotechnical Seminar Deep Foundations on Bored and Auger Piles, Ghent, Belgium (van Impe WF (ed.)). Balkema, Rotterdam, the Netherlands, pp. 193-218. van Impe WF (2004) The Overview of Almost Two Decades of Full Scale Research on Screw Piles. Laboratory of Soil Mechanics, Ghent University, Ghent, Belgium.

Wade S, Handley B and Martin J (2012) Types of bearing piles. In ICE Manual of Geotechnical Engineering, Volume II: Geotechnical Design, Construction and Verification (Burland J, Chapman T, Skinner $\mathrm{H}$ and Brown M (eds)), 1st edn. ICE Publishing, London, UK, pp. 1191-1223.

White DJ and Zhao Y (2006) A model-scale investigation into 'set-up' of displacement piles in sand. In Proceedings of the 6th International Conference on Physical Modelling in Geotechnics, Hong Kong (Ng CWW, Wang YH and Zhang LM (eds)). Taylor \& Francis, London, UK, pp. 889-894.

Young HD and Freedman RA (2000) University Physics, 10th edn. Addison Wesley Longman, San Francisco, CA, USA.

\section{HOW CAN YOU CONTRIBUTE?}

To discuss this paper, please email up to 500 words to the editor at journals@ice.org.uk. Your contribution will be forwarded to the author(s) for a reply and, if considered appropriate by the editorial board, it will be published as discussion in a future issue of the journal.

Proceedings journals rely entirely on contributions from the civil engineering profession (and allied disciplines). Information about how to submit your paper online is available at www.icevirtuallibrary.com/page/authors, where you will also find detailed author guidelines. 